\title{
On Strengthening Ideological and Political Education of College Students with WeChat
}

\author{
Yanlu $\mathrm{Li}^{1, \mathrm{a}}$ and Yue Teng ${ }^{2, \mathrm{~b}}$ * \\ ${ }^{1}$ Music college of Beihua University, Jilin, 132013 \\ ${ }^{2}$ Economics and Management of Beihua University, Jilin, 132013 \\ a124132250@qq.com, b63586841@qq.com \\ * please mark the corresponding author with an asterisk
}

Keywords: WeChat; Ideological and political education; College student.

\begin{abstract}
With the development of the times as well as the progress of the network, the application "WeChat" is gradually accepted by the public, and is especially popular in young people. WeChat has become an indispensable part of their lives. Therefore, WeChat brings a new opportunity and method on the ideological and political education of college students. Based on the in-depth analysis of the characteristics and functions of WeChat, this paper analyzes how to make full use of WeChat for ideological and political education of college students.

In early 2011, tencent launched a free program called WeChat, an intelligent terminal instant messaging service. WeChat includes instant voice calls, video calls, friends circles, picture information, public platforms, and very innovative ways of making friends, "shake", "drift bottle". This software, when used, USES traffic instead of the cost of the phone, and has been quickly developed by the public in the near future, It is now fully accessible to every mobile phone. WeChat this way of communication than a face-to-face communication is more easily accepted by students, so how to make full use of WeChat this emerging media to strengthen college students' ideological and political education has become a new topic.
\end{abstract}

\section{Application of University Students to WeChat Main Functions}

WeChat has Become an Indispensable Part in Life of Contemporary University Students. according to the college students nowadays is the most frequently used WeChat function WeChat group of information transfer, between friends and WeChat circle to share information, can be released by text with small video or some photos to communicate with other WeChat friends, other friends see also can leave a message or thumb up, is the latest after weibo communication. The characteristics of WeChat friends circle are very private, friends circle can only be seen by friends, and friends circle individuals have the right to block the information they don't want to see or want to be seen.

The Public Number is a New Way to Promote the Interactive Communication Between Video and Video. According to the number of times I pay attention to the public number in a university, the average college student has watched the WeChat public number more than four times per day. We should make full use of the interaction of the public number to increase the effectiveness of education in the public platform.

\section{WeChat's Function in the Ideological and Political Education}

By Public Circle of Friends, the Platform is Obvious Different From the Traditional Ideological and Political Education and Traditional Way of Ideological and Political Education Methods there are big Limitations Spoon-feeding Method, Single Rigid Not Easily Accepted by Modern College Students. And the idea of education through WeChat network platform as the carrier to guide transmission, will be more acceptable to contemporary college students. Highly effective ideological and political counselors can often post positive thoughts on college students through their circle of friends. We can also use the media to reprint and create some 
video which can positively influence college students' political thinking. Circle of friends can play better than the traditional ideological and political education are more likely to be accepted, the main reason is that there is a strong interactivity, the students can at any time to reply you the opinions, the result is very active interaction between teachers and students. Counselors can find out the ideas of my students in the first place, and provide psychological guidance for some students who are biased in their thoughts. This strengthens the university's ideological and political education effect, and students can gain more from it.

WeChat is the nature of the public and is presided and reading have interactive dialogue between the communication platform, the school can according to the characteristics of different school to apply for the public, further to the promotion of ideological and political education of college students, the students can subscribe to the WeChat public attention. In particular, the widely used promotion form of the public number is mainly the message group, which is also the most frequently used function of WeChat public. A background message from WeChat can be sent by sending messages to all readers or by sending them separately. Receive the message dynamic user subscribing to the public number. The school can guide the students according to the characteristics of the students in each college, and then the counselor can complete a one-to-one communication with the readers through the form of reply to the background editor of WeChat.

\section{The Counselor's Role in WECHAT}

Improve the Vocational Quality of Counselors and Infect Students with Excellent Personality. The instructor consciously learned the communication characteristics of WeChat, and made full use of these features to characterize my college students' behavioral characteristics in WeChat's life, and included them in the core system of their own career development. As the counselors carry out the education publicity work of traditional ideological and political science, they should actively integrate into the students' life and make timely and timely guidance on the bad public opinion in students with high vigilance. To develop the work to every student with meticulous work style, solve the student's confusion in time. Counselors in order to better integrate into the students should learn the annual network popular language, WeChat expressions in the process of communication will be strengthened let students feel kind were also more likely to make students accept the counselor guided by the theory.

Update Work Philosophy and Guide Students with Cutting-edge Work . We should establish the concept of students as the concept and clarify the requirement of role transformation, and build various platforms and work groups around students. Counselors construction of ideological and political education class learning guide the daily management of mental health education in areas such as employment planning work can all be WeChat exchange of propaganda and the public, and circle of friends. Dissemination of the mainstream values/release with students, instructors can also be through integration of WeChat parents and each year, enhance the interactive communication of several students, for students to create a healthy WeChat growing environment.

Multi-dimensional Education Shape Communication Idea Education. To mainstream values and culture guides the student to carry out self education is to cultivate good habits of college students, through the counselor to grasp the situation of students' situation thought and the interaction between diversification in time, understand a student real-time dynamic train the ability of college students' information screening, firm communist political beliefs. Objectively and correctly appraises the development achievements of socialism with Chinese characteristics, internalizes the core values of socialism and externalizes the form. To integrate ideological and political education into students' study and life.

Beware of the Negative Effects of WeChat. Since its birth, WeChat has broken the dependence of traditional information communication on space and time. But good and evil people mixed up in a world of WeChat filled with some illegal and unhealthy information, some decadent behind the radical ideas and various errors, ugly things also helps to college students' world outlook, the outlook on life, values brought no small impact. This serious impact of the belief that their mental cruelty, weakening their ability to value judgments and value choice, undermined the effectiveness 
of the ideological and political education have made to the instructors of the ideological and political education work brings certain difficulties. Through various ways, counselors can promote and promote timely and correct ideas of students, and revise the thoughts of students who are influenced by these negative things.

WeChat though is the new network media platform, but it is also a double-edged sword, he give us more better undertake to the student the opportunity and platform of ideological and political education, but also bring many negative effects. Counselors should strengthen ideological and moral cultivation, enhance social responsibility, and become a guide for healthy growth of college students. First of all, the spread of false information or wrong information locked well, colleges and universities in active WeChat atmosphere at the same time, to avoid false information error message transmission on WeChat, in view of the bad information to refute the WeChat, let the students timely identify fraud, in front of the students has not been shaken the understanding of the dynamic correcting students' mistakes students thought-form.

Ideological and political education on the platform of the WeChat can get better play to better effect, so as to promote college students' learning, and improve the effectiveness of ideological and political education, strengthen ideological and political education, educators and students of the education communication WeChat platform should not be constrained by the content of the theory of java script:;ideological and political education, should be more current news, focusing on the social hot topics and interact with the students to understand try to guide the student thought trend, WeChat has been widely used for college students, the ideological education workers should reasonable application WeChat platform to strengthen the ideological and political education work, improve the college students can identify and help them to set up the correct world outlook, the outlook on life, values, make WeChat not just as a multimedia software to make friends, but as a new era of big data platform of ideological and political education.

\section{Acknowledgements}

In 2017, the 13th five-year plan of education science in Jilin province is "Research on improving the effectiveness of ideological and political education of college students from the perspective of comprehensive education" (GH170091).

\section{References}

[1] A study on the effectiveness of students' political thinking in colleges and universities [J]. Chunli Zhang. Weekly. 2014(16)

[2] College students' political thinking education network model innovation [J]. Jun Ding, Jing Wang. Contemporary youth research. 2007(04)

[3] Research on the application of WeChat public platform in universities [J]. Zhiqiang Feng. Wireless Internet technology. 2013(09)

[4] Analysis of WeChat transmission mode [J]. Xiaodan DAN.News world. 2013(02)

[5] Current situation and reflection: a decade of research on the application of education in social software [J]. Yonghua Wang, Xubiao Yin, Junzheng Zhang. Modern education technology. 2013(10)

[6] the effective combination of education and psychological health education [J]. Naifang Zhang, Dongsheng Zhang. School party construction and thought education. 2010(33)

[7] Discussion on Internet auxiliary college students' political thought education [J]. Dongmei Hu. Chinese adult education. 2005(10) 